\title{
Correction to: Boundedness of spectral multipliers of generalized Laplacians on compact manifolds with boundary
}

\section{Mayukh Mukherjee ${ }^{1,2}$}

Published online: 27 July 2019

(c) The Author(s) 2019

\section{Correction to: Math. Z. (2018) 290:1479 https://doi.org/10.1007/s00209-018-2061-x}

The original version of this erratum has been published with the incorrect copyright line. The correct copyright line should read as "The Author's".

Open Access This article is distributed under the terms of the Creative Commons Attribution 4.0 International License (http://creativecommons.org/licenses/by/4.0/), which permits unrestricted use, distribution, and reproduction in any medium, provided you give appropriate credit to the original author(s) and the source, provide a link to the Creative Commons license, and indicate if changes were made.

Publisher's Note Springer Nature remains neutral with regard to jurisdictional claims in published maps and institutional affiliations.

The original article can be found online at https://doi.org/10.1007/s00209-018-2061-x.

Mayukh Mukherjee

mathmukherjee@gmail.com

1 Max Planck Institute for Mathematics, Bonn, Germany

2 Present Address: The Technion, Haifa, Israel 